Dziawgo E. (2014). Real options in the assessment of the company's pro-ecological investments. Copernican Journal of Finance \& Accounting,3(1), 61-71.http://dx.doi.org/10.12775/CJFA.2014.005

\author{
Ewa Dziawgo* \\ Nicolaus Copernicus University
}

\title{
REAL OPTIONS IN THE ASSESSMENT OF THE COMPANY'S PRO-ECOLOGICAL INVESTMENTS
}

Keywords: real options, pro-ecological investments.

J E L Classification: Q01, G11.

Abstract: The article presents the following issues related to real options: characteristics and classification of options, pricing models and analysis of the applicability of real options in the assessment of the company's pro-ecological investments. The concept of real options analysis is an innovative mainstream methodology of creating a multi-stage decision-making model to facilitate the action related to the strategic implementation of investment activities. The real options analysis method is alternative and complement to traditional methods of evaluation of investment projects.

The purpose of this article is to present the applicability of real options in the assessment of the company's pro-ecological investments.

\section{OPCJE REALNE W OCENIE PROEKOLOGICZNYCH INWESTYCJI PRZEDSIĘBIORSTWA}

Słowa kluczowe: opcje realne, proekologiczne inwestycje.

Klasyfikacja J E L: Q01, G11.

Abstrakt: W artykule przedstawiono zagadnienia związane z opcjami realnymi: charakterystykę i podział opcji, modele wyceny oraz analizę możliwości zastosowania

Date of submission: March 5, 2014; date of acceptance: March 24, 2014.

* Contact information: dziawew@umk.pl, Faculty of Economic Sciences and Management, Nicolaus Copernicus University, Gagarina 13a, 87-100 Toruń, Poland. 
opcji realnych w ocenie proekologicznych inwestycji przedsiębiorstwa. Koncepcja analizy opcji realnych jest innowacyjnym nurtem metodycznym, polegającym na stworzeniu wieloetapowego modelu decyzyjnego ułatwiającego podjęcie działań związanych ze strategicznym wdrażaniem działań inwestycyjnych. Metoda analizy opcji realnych jest alternatywą i uzupełnieniem dla tradycyjnych metod oceny projektów inwestycyjnych.

Celem artykułu jest przedstawienie możliwości zastosowania opcji realnych w ocenie proekologicznych inwestycji przedsiębiorstwa.

Translated by Ewa Dziawgo

\section{IIINTRODUCTION}

Environmental degradation, which arises out of unreasonable and improper management of renewable and non-renewable resources is a global problem of modern civilization. Environmental degradation results in higher operating costs of society and constitutes a threat to the further existence of man. Solving environmental problems requires international cooperation. The policy of the European Union lays much emphasis on the issues related to the implementation of the main objective of balanced and sustainable development, which is striving to improve the quality of life for present and future generations by taking all measures affecting the economic and social development harmonized with the rational use, mobility and protection of the natural environment. The implementation of the concept of eco-development is facilitated by the already developed economic and legal instruments of the state's environmental policy that forces the modern enterprise to adapt to environmental requirements. In the case of undertaking strategic investment activities, the company must also take into account the environmental aspect of its projects undertaken.

The concept of real options analysis can be an alternative and complement to traditional methods of evaluation of investment projects implemented by the company. Due to their flexibility, options can facilitate the management company to take environmental decisions related to business activities.

This article is also intended to present different types of real options, the use of which may significantly facilitate the pro-ecological management of the enterprise value. 


\section{THE RESEARCH METHODOLOGY AND THE COURSE OF THE RESEARCH PROCESS}

Pro-ecological investments are characterized by high flexibility. Hence, in the case of pro-environmental projects there is a need to price this flexibility, which significantly increases the economic value of the investment.

The following were realized within the article:

- analysis of the properties of real options in terms of their applicability in the evaluation of pro-environmental projects,

- based on the identified flexibility inherent in the pro-ecological projects particular categories of real options were assigned to selected pro-ecological investments,

- for selected types of real options the valuation models were indicated.

\section{PRO=ECOLOGICAL STRATEGIES IN THE COMPANY'S ACTIVITY}

Threats of environmental degradation, which arise out of business activities conducted are divided into global and local (Piontek 2002; Piontek, Piontek, Piontek 1997; Nahotko 2002; Płoska 2006; Ryszko 2007). The main global threats include the following: the greenhouse effect, ozone depletion, desertification of land, uncontrolled deforestation, and water scarcity. In turn, local threats are pollution of the atmosphere, noise, increase in the size of the electromagnetic field, environmental disasters, pollution caused by solid and liquid waste, chemical pollution, changes in the landscape. The negative effects of economic processes on the environment and the increase in the awareness of the need to counter the devastation of the environment have contributed to the development of economic and legal instruments of the state's environmental policy. These instruments contribute to the implementation of investment projects realised by companies that consider environmental elements. The following legal instruments deserve special attention: regulations that oblige entities to consider the requirements of environmental protection, emission norms, the accepted principles of eco-development as a criterion of land-use, provisions governing the rules of the obtainment of a license for a specific activity, the rules governing the conduct of environmental impact assessment, the official list of hazardous waste. In turn, the main economic instruments of the state's environmental policy include ecological charges, environmental fines, product charges, subsidies, emissions trading. 
Pro-ecological investment made by companies are investments in green technologies and in management, in which the rules are complied with environmental protection. Taking into account the aspects of the idea of environmental protection is reflected in numerous spheres of business. In particular, the pro-ecological activities of companies include the following:

- developing and implementing designs of new products, which in comparison with conventional products have a favourable impact on the environment,

- analysing the impact of the product and its manufacturing process on the environment,

- modifications of an existing product, the result of which is the achievement of a higher quality of this product while minimizing the negative impact of the manufacturing process on the environment,

- developing and introducing new technologies that reduce the consumption of raw materials and energy, and minimize the amount of waste,

- consideration of recycled materials in the product and its packaging,

- minimizing the size of the packaging,

- conducting and sponsoring scientific research in the field of introducing new products and improving manufacturing processes taking into account environmental priorities,

- ensuring safe transport and proper storage of hazardous substances,

- sponsoring environmental programs and actions.

In the process of adapting companies to the requirements of and regulations on environmental protection an increasing public awareness of environmental protection is essential. There is a favourable image of companies engaging in environmental protection and offering environmentally friendly products. Enterprises involving in their processes economic ideas of eco-development reach a competitive advantage that comes from their standing out in the market environment. It is increasingly popular nowadays to analyse both good economic performance and undertaken pro-environmental activities while attracting investors. Changes in production technologies, whose aim is to improve the environmental parameters of the functioning of the enterprise, contribute to the creation of a competitive advantage resulting from the cost advantage. Introduction of environment-friendly technology upgrades and innovation in the production process can affect the reduction of costs mainly through a more rational use of raw materials, reducing energy consumption, using for production purposes recycled materials or materials utilized in a non-toxic and ener- 
gy saving way, reducing the amount of water used in the production process, reducing carbon dioxide emissions and solid waste, applying reusable transport packaging, and through collecting used packaging.

Including the ecological modernization of production technology in economic processes requires a strategic investment decisions. In the case of environmental projects, applying an analysis of real options, which are characterized by their flexibility, can be an alternative or complement to traditional methods of evaluation of investment projects.

\section{PROPERTIES OF THE REAL OPTIONS}

A real option is the right (but not the obligation) to perform certain actions with regard to the investment project in the case when new information (conditions) appears (Amram, Kulatilaka 1999; Jajuga 2000; Ziarkowski 2004; Copeland, Anticarov 2001). Real options are characterized by flexibility which means that in the event of favourable market conditions the company takes specified actions, and, if there is an unfavourable situation for the company, then the company may resign from undertaking those actions. Real options have the following properties:

- the option is exercised when it is favourable to the buyer,

- increase of the risk associated with the project adds value to the option,

- the payoff function is characterized by asymmetry,

- there is a choice of alternatives,

- the possible reaction of the decision-maker is activated when the parameters used in the measurement change.

The concept of real options is worth implementing in the evaluation of investment projects, which are related to the concerns about the launch date of the investment, extending the scale of the project (e.g., the expansion of the company into new markets, the development of production lines in traditional industries by offering additional products), deferring investments till the moment of the occurrence of more favourable market conditions, cancelling the project, introducing new technology, acquiring new strategic competencies, developing or limiting infrastructure.

The concept of real options pricing allows quantification of the flexibility inherent in the investment project.

The value of real options is dependent on the following factors: the current value of the benefits of the investment project, investment layouts, the expiry 
time of the investment project, the discount rate being the risk-free rate, volatility of cash flows, the cash flows lost.

Real options due to their standard nature can be divided into:

- call options (the right to buy certain assets) and put options (the right to sell certain assets),

- European options (which can be exercised only on their maturity date) and (American options) (which can be exercised at any time during the period of their validity).

Taking into account undertaking additional activity and outlays within real options the following can be distinguished:

- internal options that arise from the nature of the project and do not require additional activity and outlays,

- created options, where additional outlays are required. Created options improve the company's flexibility and its ability to adapt to changing market conditions.

\section{REAL OPTIONS IN THE COMPANY'S PRO-ECOLOGICAL ACTIVITY}

Considering the specificity of real options, we can introduce the following classification of this type of options (Amram, Kulatilaka 1999; Brach 2002; Dziawgo 2009):

- options for a phased implementation of the project,

- diagnosis options,

- growth options,

- options for the flexibility of production means,

- options to expand, options to delay,

- exit options.

Options for a phased implementation of the project are characterized by being linked to a multi-stage investment, wherein each stage is dependent on the previous step. This type of option allows one to avoid the need of incurring all of the expenditures of the project. Implementation of ecological modernization and innovation can then be recognized for certain stages of the production process.

Diagnosis options are related to the possibility of a staged implementation of the investment. Based on the data collected in earlier phases of the project, decisions are made regarding further action. Examples of environmental projects considered within diagnosis options include: 
- analyses of the impact of the product on the environment, which take into account all stages of the product's life cycle,

- minimizing packaging and its toxicity for the environment,

- responsible and safe transportation and storage of hazardous substances and waste,

- reducing or eliminating the use and storage of hazardous substances and waste.

Growth options allow the extension of the company's activities on the market. A growth option is an option to buy and concerns investment projects whose initial outlay far exceed the benefits from the implementation of the project. The company uses its resources and makes investments, which in the future guarantees its expansion with new products and new technologies. Within growth options we can consider the following environmental projects:

- launching onto the market new pro-ecological products,

- implementing in the manufacturing process new technologies that use recycled materials in products,

- implementation of energy-saving technologies and technologies that reduce consumption of raw materials,

- developing and introducing new technologies that minimize the amount of waste.

Options for the flexibility of production means allow you to choose production methods and technologies depending on the type and price of raw materials, energy use, existing demand and statutory regulations. An option for the flexibility of production means has a portfolio consisting of call and put options. This option is particularly attractive when economic conditions are changing the market, where there is a risk of adverse price movements. Within an option for the flexibility of production means the following pro-ecological measures can be considered: reducing pollution at the source of their creation (change of raw materials, energy, and machinery used in the production process), the use of recycled materials, reducing the consumption of raw materials and energy, the use of recycled materials.

Options to expand allow taking the company projects that rely on periodic reducing or stopping the action and re-running them, periodically increasing (a call option) or reducing (a put option) the scale of production. The option to expand impacts the improvement of the efficiency of activities conducted. In some cases it is possible to adjust the scale of operations to the current market conditions. Within the option to expand can be considered environmentally 
friendly projects aimed at reducing the rate of exploitation of resources, taking into account the products made from recycled materials, reducing the consumption of raw materials and energy, keeping waste segregation and recycling.

Options to delay allow you to select the moment when the investment is to be commenced. If the company faces unfavourable market circumstances, this option allows avoiding unprofitable investments and losses. However, the investment may become profitable, if it is realised at a later date, under market conditions that are more favourable for the company. An option to delay is an American-style call option. An example of an option to delay is an investment made in the acquisition of land rich in natural resources. Prior to the commencement of mining, it is often necessary to perform a series of additional examinations related to a better understanding of the content of the deposit, the results of which will affect taking professional decisions related to the involvement of the appropriate production capacity. Under this option, you can analyse environmental projects aimed at reducing the amount of waste or increasing the level of recycling of waste generated.

Exit options allow you to withdraw from the project in the case when there are adverse market conditions for the company, or when adverse results of technical analysis are received. Exit options are put options. The exit option often occurs along with the growth option. Examples of environmental projects within exit options include the following: considering while buying the environmental attributes of the offered goods, conducting research and development activity in the area of sourcing recycled materials, conducting research in the area of attracting new sources of raw materials, participating in the transfer of techniques and environmental technologies.

\section{PRICING MODEL OF THE REAL OPTIONS}

In pricing of real options the most frequently applied models include the Black-Scholes model (a continuous model) and the Cox-Ross-Rubinstein option pricing model (a binomial model) (Amram, Kulatilaka 1999; Brach 2002; Copeland, Anticarov 2001; Trigeorgis 1999; Dziawgo 2003). The Black-Scholes model assumes that the value of the underlying asset changes continuously. This model is used for European-style options. The value of a real call option derived from the application of the Black-Scholes model at the $t$ moment is:

$R O V_{t}(K)=V \cdot N\left(d_{1}\right)-I \cdot e^{-r(T-t)} N\left(d_{2}\right)$ 
where:

$R O V_{t}(K)$ - the value of the call real option at the time, $V$ - the current value of the cash flows generated by the investment, $r$ - risk-free interest rate, $I$ - the current value of the expenditure related to the investment, $T$ - time to the option expiration, $t \in[0, T], N(d)$ - cumulative probability function for a standard normal variable distribution, $\sigma$ - the coefficient of volatility of the cash flows generated by the investment,

$$
N(d)=\frac{1}{\sqrt{2 \pi}} \int_{-\infty}^{d} e^{\frac{-x^{2}}{2}} d x, d_{1}=\frac{\ln \frac{V}{I}+\left(r+\frac{\sigma^{2}}{2}\right) \cdot \sqrt{T-t}}{\sigma}, d_{2}=d_{1}-\sigma \sqrt{T-t} .
$$

The value of the put real option at the time $t$ is:

$$
R O V_{t}(S)=I \cdot e^{-r(T-t)} N\left(-d_{2}\right)-V \cdot N\left(-d_{1}\right)
$$

where:

$R O V_{t}(S)$ - the value of the put real option at the time $t$, other designations remain the same as in formula (1).

It is assumed in the Cox-Ross-Rubinstein that the value of the underlying asset changes in a discrete manner, i.e., changes in the value of the underlying asset are abrupt. This model is used in the evaluation of options of both European and American. Using a binomial model, the value of a call real option (with moments of realization) is the following:

$$
R O V_{t}(\bar{K})=V \sum_{k=k_{0}}^{N}\left(\begin{array}{l}
N \\
k
\end{array}\right) q^{k}(1-q)^{N-k}-\frac{I}{(1+r)^{N}} \sum_{k=k_{0}}^{N}\left(\begin{array}{l}
N \\
k
\end{array}\right) p^{k}(1-p)^{N-k},
$$

where:

$R O V_{t}(\bar{K})$ - the value of the call real option at the time $t, u$ - an increase factor in the value of the underlying asset, $d$ - a fall factor of the underlying asset,

$$
d<1+r<u \text {, }
$$

$$
q=\frac{u}{1+r} p, \quad p=\frac{1+r-d}{u-d}, \quad k_{0}=\min \left\{j \in N ; V_{0} u^{j} d^{N-j}>I\right\},
$$

other designations remain the same as in formula (1).

A binomial pricing model of a put real option takes the following form: 
$\operatorname{ROV}_{t}(\bar{S})=\frac{I}{(1+r)^{N}} \sum_{k=k_{0}}^{N}\left(\begin{array}{l}N \\ k\end{array}\right) p^{k}(1-p)^{N-k}-V \sum_{k=k_{0}}^{N}\left(\begin{array}{l}N \\ N\end{array}\right) q^{k}(1-q)^{N-k}$,

where:

$\operatorname{ROV}_{t}(\bar{S})$ - the value of the put real option at the time $t$,

$k_{0}=\min \left\{j \in N ; V_{0} u^{j} d^{N-j}<I\right\}$,

other designations remain the same as in formula (3).

If the binomial model has an increasing number of the moments of realization, the result obtained from this model is close to the value of the real option derived from the Black-Scholes model.

\section{UIICLNIONS}

Pro-ecological investments are often characterized by the following properties:

- in the initial phase of their implementation, significant financial outlays are incurred,

- in a longer time period they may affect the reduction of costs related to the functioning of the company.

Traditional methods of the evaluation of investment projects (e.g., the Net Present Value method) may understate the value of some of the analysed environmental investment projects, because these methods do not consider the possibility of active management of the project. The company which has real options can create favourable conditions for themselves, and thus affect the environment. Real options analysis allows measurement of projects due to the selected direction, the moment of realization and type of investment. In the case of real options, there is a possibility of a controlled increase of its value. Real options create a valuable picture of the generated flexibility. Therefore, the real options analysis method is particularly attractive in the evaluation of pro-ecological investment projects.

However, in the case of real options, correct variable valuing $^{2}$ and periodic verification is necessity.

1 Which take a stand in model of pricing.

${ }^{2}$ Are calculated with the use of the advanced simulation methods. 


\section{REFERENCES}

Amram M., Kulatilaka N. (1999), Real Options, Managing Investments in an Uncertain World, HBS Press, Boston.

Brach M. A. (2002), Real options in practice, John Wiley \&Sons, Inc, New York, 105-130.

Copeland T., Anticarov V. (2001), Real options: A practitioner's guide, Texere, New York.

Dziawgo E. (2003), Modele kontraktów opcyjnych, Wydawnictwo Naukowe Uniwersytetu Mikołaja Kopernika, Toruń, 97-100.

Dziawgo E. (2009), Opcje rzeczowe w proekologicznych strategiach przedsiębiorstwa, [in:] Funkcjonowanie przedsiębiorstw w warunkach zrównoważonego rozwoju i gospodarki opartej na wiedzy, E. Sidorczuk-Pietraszko (ed.), Wydawnictwo Wyższej Szkoły Ekonomicznej w Białymstoku, Białystok, 261-269.

Jajuga T. (2000). Opcja rzeczowa - nowy instrument pochodny czy przełom w zarządzaniu finansami. Rynek Terminowy, 9 (3), 88-92.

Nahotko S. (2002), Podstawy ekologicznego zarządzania przedsiębiorstwem, Oficyna Wydawnicza Ośrodka Postępu Organizacyjnego, Bydgoszcz, 81-88.

Piontek B. (2002), Koncepcja rozwoju zrównoważonego i trwałego Polski, Wydawnictwo Naukowe PWN, Warszawa-Kraków.

Piontek B., Piontek F., Piontek W. (1997), Ekorozwój i narzędzia jego realizacji, Wydawnictwo Ekonomia i Środowisko, Białystok.

Płoska R. (2006), Proekologiczne działania przedsiębiorstwa jako podstawa budowania przewagi konkurencyjnej, [in:] Strategia Lizbońska a zarządzanie wartością, L. Pawłowicz (ed.), CeDeWu, Warszawa, 127-137.

Ryszko A., (2007), Proaktywność przedsiębiorstw w zarządzaniu środowiskiem, determinanty, mierniki i efekty, [in:] Zrównoważony rozwój i ochrona środowiska w gospodarce, D. Kiełczewski, B. Dobrzańska (ed.), Wydawnictwo Wyższej Szkoły Ekonomicznej w Białymstoku, Białystok, 345-359.

Trigeorgis L. (1999), Real options: A primer [in:] The new investment theory of real options and its implication for telecommunications economics, J. Alleman, E. Noam (ed.), Kluwer Academic Publishers, Boston, 3-34.

Ziarkowski R. (2004), Opcje rzeczowe oraz ich zastosowanie w formułowaniu i ocenie projektów inwestycyjnych, Wydawnictwo Akademii Ekonomicznej w Katowicach, Katowice. 
